\title{
University of Florida Potato Variety Trials Spotlight: “Elkton”
}

\author{
Mario H. M. L. Andrade, Lincoln Zotarelli, Douglas Gergela, and Kathleen Haynes²
}

There are several potato varieties available in the market today. Most of them have been bred or developed in production regions other than Florida. The University of Florida Potato Variety Evaluation Program screens new germplasm from public and private breeding programs and identifies the most promising cultivars for commercial potential considering broad adaptability to Florida climate and conditions and market purpose: processing, freshmarket and specialty-type varieties. Over the years, the UF/ IFAS Potato Variety Program has become an important reference to vegetable growers, seed producers, processors, crop insurance agencies, and brokers looking for alternative potato varieties to explore different markets, improved characteristics, and yield. This UF/IFAS Potato Variety Trials Spotlight presents a summary of the field evaluation of tuber yield and quality performance of the potato variety 'Elkton' cultivated in Florida.

\section{General Comments}

'Elkton' is a white-flesh potato variety suitable for chipping directly from the field (Figures 1 and 2). 'Elkton' was selected from the USDA-ARS breeding program in Beltsville, Maryland, by Dr. Haynes in 1997. In 2003, seed of 'Elkton' was made available for field evaluation under Florida growing conditions. In 60 trials conducted between 2003 and 2018, 'Elkton' yielded 112\% in comparison with 'Atlantic' (Table 1). In these trials, 'Elkton' demonstrated resistance to internal heat necrosis and hollow heart, which are common tuber physiological disorders under hightemperature growing conditions.

\section{General Characteristics}

'Elkton' has white flesh with netted light-tan skin. Tubers are round to oval and medium-thick with intermediate to shallow eye depth (Figure 1). Tubers have a short dormancy period. The variety has good yield potential, specific gravity slightly lower than 'Atlantic' (Table 1), and similar chip color to 'Atlantic'.

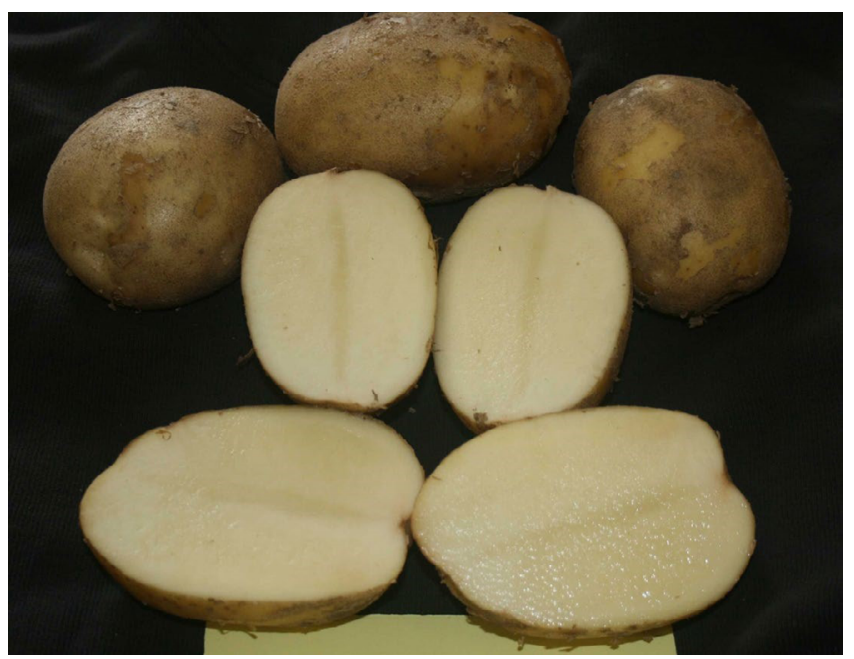

Figure 1. Typical tuber set and internal flesh color of 'Elkton'. Credits: Dana Fourman.

1. This document is HS1237, one of a series of the Horticultural Sciences Department, UF/IFAS Extension. Original publication date April 2014. Revised April 2020 and February 2021. Visit the EDIS website at https://edis.ifas.ufl.edu.

2. Mario H. M. L. Andrade, research scholar; Lincoln Zotarelli, associate professor, Horticultural Sciences Department; Douglas Gergela, former Research Coordinator of Hastings Agricultural and Extension Center; Kathleen Haynes, retired breeder, Genetic Improvement of Fruits and Vegetables Laboratory, USDA-ARS, Beltsville, MD; UF/IFAS Extension, Gainesville, FL 32611.

The Institute of Food and Agricultural Sciences (IFAS) is an Equal Opportunity Institution authorized to provide research, educational information and other services

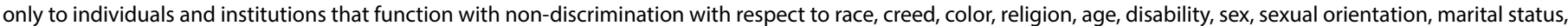

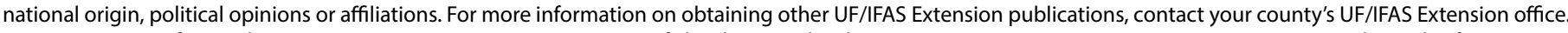
U.S. Department of Agriculture, UF/IFAS Extension Service, University of Florida, IFAS, Florida A \& M University Cooperative Extension Program, and Boards of County Commissioners Cooperating. Nick T. Place, dean for UF/IFAS Extension. 


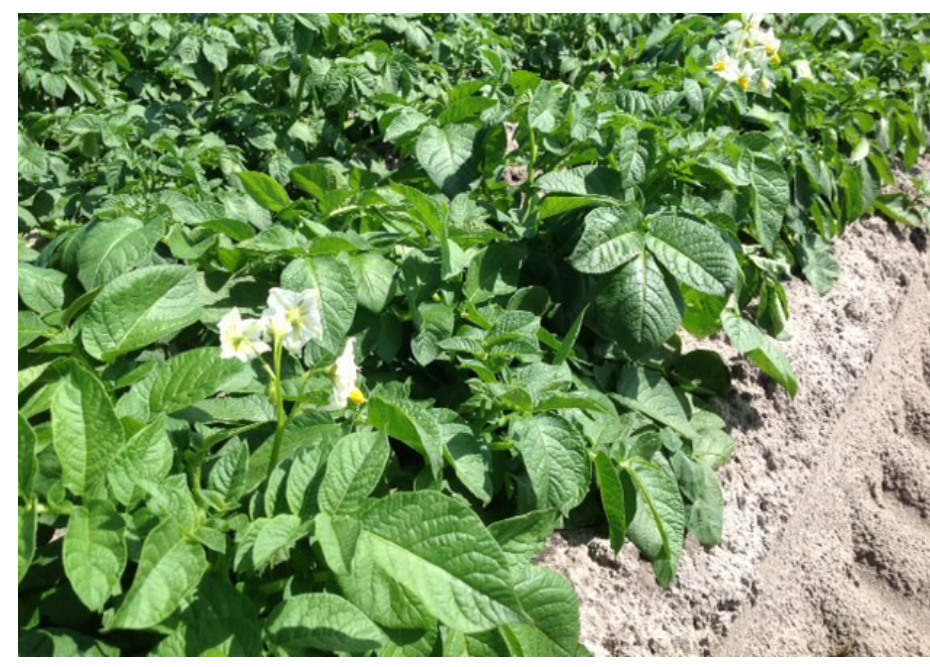

Figure 2. 'Elkton' plants during flowering stage.

Credits: Dana Fourman.

\section{Season Length and Growth}

'Elkton' has a medium to medium-late maturity, approximately 95-105 days, depending on growing conditions during the season. Tuber size should be checked regularly late in the season. 'Elkton' typically shows slower initial growth compared to 'Atlantic' planted at the same time; however, during vegetative development, 'Elkton' shows similar plant size to 'Atlantic'.

\section{Fertilization}

University of Florida trial plots were fertilized with $200 \mathrm{lb} /$ acre of $\mathrm{N}$, with $50 \mathrm{lb} / \mathrm{acre}$ of $\mathrm{N}$ (granular) incorporated into the beds prior to planting, followed by two split side-dress fertilizer applications of $75 \mathrm{lb} /$ acre of $\mathrm{N}$ each at emergence and at tuber initiation. Phosphorus and potassium applications follow the UF/IFAS guidelines described in Liu et al. (2020) and normally range between 45 to $100 \mathrm{lb} / \mathrm{A}$ of $\mathrm{P}_{2} \mathrm{O}_{5}$ and 170 to $235 \mathrm{lb} / \mathrm{A}$ of $\mathrm{K}_{2} \mathrm{O}$.

\section{Planting}

A seed piece of $2 \frac{1}{2}$ to $3 \mathrm{oz}$ is desired for planting. Plant spacing should be 5 to 8 inches in-row with 36 to 40 inches between rows. Excessive soil moisture late in the season will degrade lenticel appearance.

\section{Diseases and Weed Control}

'Elkton' appears to be moderately resistant to early blight and verticilium wilt, but the latter still needs confirmation. 'Elkton' has shown moderate susceptibility to both foliar and tuber late blight. 'Elkton' is moderately susceptible to powdery scab, virus $\mathrm{Y}$ and virus $\mathrm{S}$. A standard Extensionrecommended disease and weed control program is described in EDIS publication CV131, Potato Production (part of the Vegetable Production Handbook for Florida).

\section{References}

Haynes, K. G., D. M. Gergela, X. S. Qu, M. W. Peck, G. C. Yencho, M. E. Clough, M. R. Henninger, et al. 2014. "Elkton: A new potato variety with resistance to internal heat necrosis and hollow heart and suitable for chipping directly from the field in the southern United States." American Journal of Potato Research, 91 (3): 269-276.

Liu, G., E. H. Simonne, K. T. Morgan, G. J. Hochmuth, S. Agehara, and R. Mylavarapu. 2020. Chapter 2. Fertilizer Management for Vegetable Production in Florida. In Vegetable Production Handbook for Florida, 2020-2021 Edition. CV296. Gainesville: University of Florida Institute of Food and Agricultural Sciences. https://edis.ifas.ufl.edu/cv296 
Table 1. Summary of production statistics and specific gravity of 'Elkton', a chipping potato variety grown at the UF/IFAS research and demonstration farm in Hastings, Florida.

\begin{tabular}{|c|c|c|c|c|c|c|c|c|c|c|c|c|}
\hline \multirow[t]{3}{*}{ Year } & \multirow{3}{*}{$\begin{array}{c}\text { Total } \\
\text { Yield } \\
\text { (cwt/ac) }\end{array}$} & \multirow{3}{*}{$\begin{array}{c}\text { Marketable } \\
\text { Yield }^{1}\end{array}$} & \multirow{3}{*}{$\begin{array}{c}\% \text { of } \\
\text { Atlantic }\end{array}$} & \multicolumn{7}{|c|}{ Size Class $^{2}$} & \multirow{3}{*}{\multicolumn{2}{|c|}{$\begin{array}{l}\text { Specific } \\
\text { Gravity }\end{array}$}} \\
\hline & & & & \multicolumn{6}{|c|}{ Distribution by Class \% } & Range \% & & \\
\hline & & & & $\mathbf{C}$ & B & A1 & A2 & A3 & A4 & $\begin{array}{c}\text { A1 to } \\
\text { A3 }\end{array}$ & & \\
\hline 2004 & 416.4 & 369.0 & 101 & 5.7 & 5.4 & 48.8 & 32.8 & 7.2 & 0.2 & 88.7 & 0.9 & 1.079 \\
\hline 2005 & 415.8 & 356.2 & 113 & 0.9 & 11.8 & 54.7 & 24.2 & 8.4 & 0.0 & 87.3 & 2.0 & 1.079 \\
\hline 2006 & 500.5 & 448.4 & 121 & 0.9 & 6.0 & 71.0 & 20.5 & 1.6 & 0.0 & 93.1 & 3.8 & 1.087 \\
\hline 2007 & 436.1 & 396.2 & 120 & 0.9 & 5.8 & 54.4 & 23.3 & 15.2 & 0.3 & 92.9 & 2.4 & 1.076 \\
\hline 2008 & 469.3 & 415.3 & 144 & 1.5 & 8.8 & 62.0 & 20.0 & 7.7 & 0.0 & 89.8 & 1.8 & 1.083 \\
\hline 2009 & 456.0 & 343.7 & 120 & 1.2 & 7.5 & 52.2 & 23.3 & 14.9 & 0.9 & 90.3 & 7.2 & 1.061 \\
\hline 2010 & 388.4 & 232.7 & 83 & 4.3 & 33.5 & 59.6 & 2.1 & 0.5 & 0.0 & 62.2 & 4.6 & 1.068 \\
\hline 2011 & 332.5 & 281.2 & 110 & 2.3 & 9.8 & 62.6 & 18.2 & 7.1 & 0.0 & 87.9 & 4.1 & 1.075 \\
\hline 2012 & 399.4 & 360.8 & 90 & 0.7 & 3.6 & 31.6 & 26.7 & 34.5 & 2.8 & 92.9 & 3.4 & 1.083 \\
\hline Average & 423.8 & 355.9 & $111 \%$ & 2.0 & 10.2 & 55.2 & 21.2 & 10.8 & 0.5 & 87.2 & 3.4 & 1.077 \\
\hline
\end{tabular}

Table 2. Florida rating codes for potato tuber characteristics. ${ }^{1}$

\begin{tabular}{|c|c|c|c|c|c|c|c|}
\hline \multicolumn{8}{|c|}{ Tuber Characteristics } \\
\hline Rating & Vine & Internal & Skin & Skin & Tuber & Eye & Overall \\
\hline Code & Maturity & Flesh Color & Color & Texture & Shape & Depth & Appearance \\
\hline 1 & Dead & White & Purple & Partial russet & round & Very deep & Very poor \\
\hline 2 & +- & Cream & Red & Heavy russet & Mostly round & -- & -- \\
\hline 3 & $\begin{array}{l}\text { Yellow and } \\
\text { dying }\end{array}$ & Light yellow & Pink & $\begin{array}{l}\text { Moderate } \\
\text { russet }\end{array}$ & $\begin{array}{l}\text { Round to } \\
\text { oblong }\end{array}$ & Deep & Poor \\
\hline 4 & +- & Medium yellow & Dark brown & Light russet & Mostly oblong & -- & -- \\
\hline 5 & $\begin{array}{l}\text { Moderately } \\
\text { senesced }\end{array}$ & Dark yellow & Brown & netted & oblong & Intermediate & Fair \\
\hline 6 & +- & Pink & Tan & Slightly netted & Oblong to long & -- & -- \\
\hline 7 & $\begin{array}{l}\text { Starting to } \\
\text { senesce }\end{array}$ & Red & Buff & $\begin{array}{l}\text { Moderately } \\
\text { smooth }\end{array}$ & Mostly long & Shallow & Good \\
\hline 8 & +- & Blue & White & Smooth & Long & -- & -- \\
\hline 9 & $\begin{array}{l}\text { Green and } \\
\text { vigorous }\end{array}$ & Purple & Cream & Very smooth & Cylindrical & Very shallow & Excellent \\
\hline
\end{tabular}


Table 3. Vine maturity, tuber characteristics, and internal tuber defects of 'Elkton', a chipping potato variety grown at the UF/IFAS research and demonstration farm in Hastings. Florida.

\begin{tabular}{|c|c|c|c|c|c|c|c|c|c|c|c|}
\hline \multirow[b]{2}{*}{ Year } & \multirow{2}{*}{$\begin{array}{l}\text { Vine } \\
\text { Maturity } \\
\text { (vine kill) }\end{array}$} & \multicolumn{6}{|c|}{ Tuber Characteristics (Ratings) } & \multicolumn{4}{|c|}{ Internal Defects $\%^{2}$} \\
\hline & & IFC & SC & ST & TS & ED & APP & $\mathbf{H H}$ & BR & CRS & IHN \\
\hline 2003 & 5.9 & 1.8 & 5.8 & 4.8 & 3.5 & 6.8 & 6.2 & 0.0 & 0.0 & 0.0 & 0.0 \\
\hline 2004 & 6.3 & 1.2 & 6.3 & 5.0 & 3.6 & 7.2 & 5.4 & 0.0 & 0.0 & 8.8 & 2.1 \\
\hline 2005 & $\mathrm{n} / \mathrm{a}$ & 1.0 & 5.0 & 4.5 & 4.5 & 6.5 & 5.5 & 0.0 & 0.0 & 0.0 & 0.0 \\
\hline 2006 & 7.5 & 1.5 & 6.8 & 5.5 & 3.5 & 7.0 & 7.2 & 0.0 & 0.0 & 0.0 & 0.0 \\
\hline 2007 & 5.8 & 1.7 & 6.2 & 4.9 & 3.0 & 6.9 & 6.3 & 0.0 & 0.0 & 0.0 & 0.3 \\
\hline 2008 & 5.5 & 1.8 & 5.7 & 5.3 & 3.7 & 5.3 & 5.7 & 0.0 & 0.0 & 0.0 & 0.0 \\
\hline 2009 & 6.9 & 1.0 & 6.0 & 5.0 & 4.0 & 6.0 & 6.0 & 1.3 & 0.0 & 0.0 & 1.3 \\
\hline 2010 & 4.4 & 1.5 & 6.0 & 5.0 & 3.5 & 5.5 & 6.2 & 0.0 & 0.0 & 2.0 & 1.3 \\
\hline 2011 & 5.5 & 2.0 & 6.0 & 5.0 & 3.0 & 5.0 & 7.0 & 0.0 & 0.0 & 0.0 & 0.0 \\
\hline 2012 & 6.0 & 1.5 & 6.0 & 5.0 & 3.6 & 6.3 & 6.2 & 0.1 & 0.0 & 1.2 & 0.5 \\
\hline 2013 & 5.9 & 1.8 & 5.8 & 4.8 & 3.5 & 6.8 & 6.2 & 0.0 & 0.0 & 0.0 & 0.0 \\
\hline Average & 6.0 & 1.5 & 6.0 & 5.0 & 3.6 & 6.3 & 6.2 & 0.1 & 0.0 & 1.1 & 0.5 \\
\hline \multicolumn{12}{|c|}{$\begin{array}{l}\text { 'See rating system outlined in Florida Rating Code Table (Table } 3 \text { ). } \\
{ }^{2} \text { Percent tuber defects. } \mathrm{HH}=\text { hollow heart, } \mathrm{BR}=\text { brown rot, } \mathrm{CRS}=\text { corky ring spot, IHN=internal heat necrosis. } \\
\mathrm{n} / \mathrm{a}=\text { not available }\end{array}$} \\
\hline
\end{tabular}

